\title{
Relationship Marketing in Insurance Industry: A Systematic Analysis of Literatures.
}

\author{
Nurul Aida Harun ${ }^{1}$, Mohd Nazri Mohd Noor ${ }^{2}$, Afrah Hayati Abdul Rahman ${ }^{3}$ \\ ${ }^{1}$ UniversitiTeknologi MARA, Melaka and Malaysia, $\square$ (nurulaida552@melaka.uitm.edu.my) \\ ${ }^{2}$ UniversitiMultimedia,Melaka and Malaysia, $\square$ (nazrizam2003@gmail.com) \\ 3UniversitiTeknologi MARA, Melaka and Malaysia, $\square$ (afrahhayati@melaka.uitm.edu.my)
}

\begin{abstract}
The relationship marketing is important in the service industry especially the one involved the complex, highly intangible services such as life insurance. By reproducing the theoretical based for the study, this paper has acknowledged different determinant of interaction and different impacts on the insurance industry. Considering this theoretical and conceptual diversity, the aim of this paper is to review and summarize the literature dealing with relationship marketing. Indeed, the goal is to realize a descriptive analysis of empirical literature focusing on the conceptualization, measurement, antecedents of relationship marketing, and to provide an integrative model for these antecedents and consequences. The recommended framework may serve as the practical guide for the insurance company in their marketing strategies and increase their competitive advantage.
\end{abstract}

Keywords: relationship marketing, insurance, systematic analysis, literature review

\section{Introduction}

Insurance defined as "a system under which the insurer, for a consideration usually agreed upon in advance, promises to reimburse the insured or to render services to the insured in the event that certain accidental occurrences result in losses during a given period" (Mark Richard Greene, 2017). According to the Life Insurance Association Malaysia (LIAM) insurance industry is the key financial pillar to the Malaysian economy because of the progressive and stable condition since the last four decades. However, Bank Negara Malaysia stated that the industry contributing only 3\% to Malaysia's Gross Domestic Product was considered low compared to other country such as Taiwan, Hong Kong, Japan and Singapore.

Furthermore, insurance and takaful sector combined assets of RM209 billion, solitary contributed about 3\% of Malaysia's Gross National Income. The government target to have $75 \%$ minimum Malaysian insured by the year 2020 compared to 56\% Malaysian currently insured. The market penetration of 30 million population of Malaysian still considered low since only around 12.4 million policyholders. The industry need more effort in addressing the gap of untapped market (Life Insurance Association Malaysia (LIAM), 2016). Among the countries in Southeast Asia region, Malaysia is claimed to have the most attractive insurance markets because of the young population coupled with the low insurance penetration rate (Nancy M. Puccinelli, Susan A. Andrzejewski, Ereni Markos, Tracy Noga, \& Scott Motyka, 2013).

Bank Negara Malaysia stated that the ability of the domestic insurance industry to capture a share will depend on the ability of the insurers to maintain their competitive positions both within the industry specifically. The major challenges face by the insurance companies are increasing competition from the traditional players as global trends of alliance and specialization create international insurers that are larger and highly skilled. Moreover, competition from new players such as asset managers, captive insurers, independent financial advisers and internet players also adjusting to the technological advances that have eventually changed the way business functioned 
and meeting the needs of more sophisticated and more knowledgeable consumers. Malaysian insurance industry need to do necessary changes to raise the performance standards and narrowing the gap between the established international best practices and performance standards.

One of the changes need to be done is the distribution channels such as independent financial advisor, banks, telephone, direct mail and the internet should be developed for the convenience of consumers. Webster Jr., (1994) adds that customers have become the companies' most valuable assets as competition in the life insurance industry grown tremendously. By conserving the long term relationship with the existing customer and increasing their satisfaction plus loyalty are highly associated to the company profitability (Sweeney, Soutar, \& Mccoll-kennedy, 2011)and sustaining competitive advantage (Sharma, Tzokas, Saren, \& Kyziridis, 1999). As Yu \& Tung (2014) notes that insurance is an example of a complex service and normally customers do not have the idea of what there are getting into. The insurance company need to make sure that the customer remains with the company.

Although the significance of relationship marketing has been acknowledged and recommended as a strategy to overcome service intangibility (Berry, 1983), the theoretical base of relationship orientation in banking and insurance services has established only slight attention(Shetty \& Basri, 2017). Thus, the objective of this paper is to determine variables related to relationship marketing in insurance industry. Apart from that, it also aims to identify the major factors that would contribute to the successful relationship marketing. From the academic perspective, this research has a significant contribution in terms of explaining the importance of successful relationship marketing (competitive advantages) and the variables contribute to it, so it can shape the insurance industry players. Understanding the variables is important to assist the industry players to be more sensitive to the needs and wants of their customers. This research also adds a new perspective to the relationship marketing literature from the context of how the variables influence the consumers of insurance industry to have a long relationship with the insurance companies.

\section{Methods}

The research followed a systematic technique to the literature search. The initial phase of literature search was achieved through an extensive search using Google Scholar. It generated a total of 4210 journal articles. The keywords of this research comprise'relationship marketing' and insurance industry'. Narrowing the initial search of journal article from 2013-2018 has yield a total of 1660 journal article. Besides, to search more related journal articles, manual search through reference also be performed. In identifying the most related journal articles in the field, the search involved the keywords 'relationship marketing' in Science Direct(http://www.sciencedirect.com/),Emerald Publishing (http://www.emeraldinsight.com/), and ProQuest Databases (https://www.proquest.com/).

The second phase was to select the most pertinent journal articles for the systematic analysis, gauging the title and the abstract. To analyses the more recently published academic literature construct, the search protocol focused on academic publications written in English and published from 2013 to 2018. The year 2013 was chosen because we want to focus on the most recent publication. Journals articles selected covered most regions mainly from Asia, Europe and Africa. These selected journals article were analyzed and resulted in identification of 240 articles, however only nine remained after the second phase of the screening process.

Table 1 Exclusion Criteria

\begin{tabular}{lll}
\hline No & Criteria & Reasons for Exclusion \\
\hline 1 & Pre 2013 & $\begin{array}{l}\text { Considering the current journal article related to the topic } \\
\text { only }\end{array}$ \\
2. & Abstract & Too simple and subjective \\
\hline
\end{tabular}


Table 2 Inclusion Criteria

\begin{tabular}{lll}
\hline No & Criteria & Reasons for Inclusion \\
\hline 1 & Academic Publication & $\begin{array}{l}\text { Peer reviewed journal articles } \\
\text { Most relevant journals in the area research are written in this } \\
\text { language }\end{array}$ \\
3. & $\begin{array}{l}\text { Published in English } \\
\text { Quantitative/qualitative/ } \\
\text { conceptual }\end{array}$ & $\begin{array}{l}\text { To reproduce empirical evidence and literature reviews } \\
\text { 4. }\end{array}$ \\
Relationship Marketing & Long term relationship & $\begin{array}{l}\text { Area of research } \\
\text { Similar to relationship marketing }\end{array}$ \\
\hline
\end{tabular}
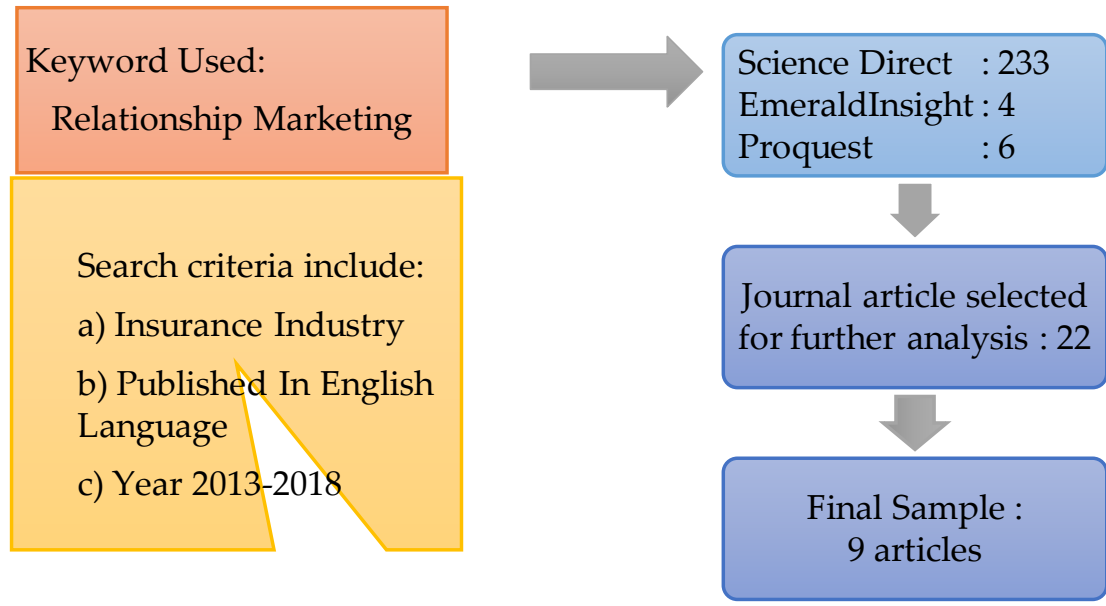

Figure 1: Structure of literature search relating to Relationship Marketing.

\section{Results and Discussion}

Relationship marketing

A long-term relationship orientation means that new interactions are affected by the results of past interactions. In a recent article by Sieg, Fischer, Wallin, \& Von Krogh (2013) stated that customer relationships are the "bread and butter" of any professional service firms. Madhavaram, Granot, \& Badrinarayanan, (2004); Yu \& Tung, (2014) verify that in the service industry the first to mention the relationship marketing was Berry (1983).Relationship marketing emphasizes the importance of establishing, maintaining and enhancing relationships between customers and buyers, in comparison to the transactional orientation of the classical marketing paradigm (Grönroos, 2004).In a book of relationship marketing, Palmatier (2008)proposes the following definition of relationship marketing: "relationship marketing is the process of identifying, developing, maintaining, and terminating relational exchanges with the purpose of enhancing performance".

Whyatt \& Koschek (2003) observed that successful relationship marketing supports in forming loyal customers begin favorable word-of-mouth and decreasing the costs of cultivating potential customers. O'Malley \& Prothero (2004)added that relationship marketing is common way in many business-to-consumer settings, is an significant source of a sustainable competitive advantage and is a perilous factor (Gummesson, 2002). As Šonková \& Grabowska (2015) explained that relationship marketing highlight on customer retention meaning that firms make action to keep their existing customers relatively than to attract new ones thus create strong long-term relationships. Relationship marketing is the most suitable strategy selection for service providing firms as services are intangible and it is vital to gain trust and convince the customers about the quality of service (Palmatier, 2008). Other than that, aim of relationship marketing is to create value for the client by distinguishing their offering from the competitor's(Šonková \& Grabowska, 2015). 
Trust

The notion of trust circles around trust on the organization and salesperson (Panda, 2013). Morgan \& Hunt (1994)point that the development of trust is refer as an important criterion for developing the buyer-seller relationship quality in financial services. Two characteristics of trust as measured in prior studies are trusting behaviors and perceived trustworthiness (Shetty \& Basri, 2017).It is recommended that trust enriches the relationship quality, which increase the customer satisfaction that will resulted in increases sales effectiveness (Palmatier, Dant, Grewal, \& Evans, 2006). From the review of the literature, this key characteristic has been mentioned in six journal articles.

\section{Commitment}

Commitment to the relationship is defined as a continuing want to uphold a valued relationship (Moorman, Zaltman, \& Deshpandé, 1992). Consequently, Panda (2013a) adds that a relationship exists when the relationship is crucial to both the both parties and require them to put intensive effort to maintain and defend this relationship for future and long term advantage. Moreover, ccommitment are important because they inspire marketers to work at conserving relationship investments by cooperating with exchange partner; resist attractive short term offers in favor of the anticipated long term advantages of remaining with existing partners.(Morgan \& Hunt, 1994). Commitment has been mentioned in five journal articles as the key characteristic to successful relationship marketing.

\section{Satisfaction}

Rajeswari \& Kartheeswari (2011)determined the customer satisfaction as the insight of customers on the service whether that service has met his needs and expectations. Customer satisfaction can be deemed as the ultimate result in the modern marketing; hence, the success of each business firmrely on recognizing and satisfying the greater customers' needs and wants (Abtin \& Pouramiri, 2016). Murugesan \& Thirumoorthi (2014)claimed that serviceand product quality, personal and situational factors, perception of equity and fairness, price and attributions for service success or failure are the factors that affect the customer satisfaction. This key characteristic has been mentioned in five journal articles.

\section{Reputation}

Echchakoui (2016) states one of the utmost valued intangible assets to increase company worth is corporate reputation. From the global perspective reputation is related with the reliability of the organizationand that is the consequence of the contrast between what the company offers and what it eventually deliver(Anabela \& Arnaldo, 2015).(Weiss, Anderson, \& MacInnis, 1999)demarcated reputation as "in a global perception of the extent to which an organization is held in high esteem or regard." As a result, Anabela \& Arnaldo (2015) defined reputation as "a perceptual representation of a company's past actions and future prospects that describe the firm's overall appeal to all its key constituents when compared to other leading rivals". Basic component of reputation evaluation (fairness, honesty, and concern) were specified by authors (e.g.Palmatier, Scheer, Evans, \& Arnold, (2008))as important ingredients of relationship marketing(Echchakoui, 2016).From the systematic analysis done only one journal article mention about this key characteristic.

Perceived value

The meaningintroduced by (Zeithaml, 1988)is one of the most commonlyacknowledged which defines value as anexchange between the benefits and costsrelated with a supplier's offering as perceived by the consumer (Woodruff, 1997; Zeithaml, 1988).Lai, Griffin, \& Babin (2009), believes that perceived value is an imperative predictor of customer loyalty and similar as Spiteri and Dion (2004) also point out that the customer perceived value is positively associated with loyalty behavior. Anabela \& Arnaldo (2015) explain value as from the customer's perspective and can be recognized as perceived value or a key driver of choice. In spite, customer-perceived value is comprised of multidimensional constructs, majority of empirical tests of insurance value models adopt a practical 
perspective focusing value as the quality connected to the price paid, or above all "value for money" (Anabela \& Arnaldo, 2015). This key characteristic was mention only in one journal article.

\section{Management, Communication and Competency}

Echchakoui (2015) regards communication as an instrument of value creation and that salespeople not only communicate value but must also create it (Rackham \& DeVincentis, 1999). Whereas, competent defined as an organizational ability as "a high-level routine (or collection of routines) that, together with its implementing input flows, confers upon an organization's management a set of decision options for producing significant outputs of a particular type" (Winter, 2003). The these key characteristics found in only one journal article and it is not clearly discuss in that journal article.

From the systematic review done, the researcher discovered that successful, effectiveness and longstanding relationship with the customer resulted from the existence of commitment, trust (Morgan \& Hunt, 1994; Epetimehin, 2011; Yu\& Chen, 2014; Yu \& Tung, 2014; Murugesan \&Thirumoorthi, 2014;Abtin\&Pouramiri, 2016 and Shetty \&Basri, 2017) and satisfaction (Yu \& Chen, 2014; Shetty \&Basri, 2017; Yu \& Tung, 2014; Epetimehin, 2011;Abtin\&Pouramiri, 2016; Murugesan \&Thirumoorthi, 2014). Table 3 documented the key characteristics of relationship marketing in the journal articles selected.

Table 3 Journal Articles Selected in Systematic Analysis of Relationship Marketing.

\begin{tabular}{|c|c|c|c|c|c|}
\hline Journal & Title of article & Author(s) & Year & $\begin{array}{l}\text { Key } \\
\text { characteristics/ } \\
\text { Variable observed }\end{array}$ & $\begin{array}{l}\text { Country/ Type } \\
\text { of relationship } \\
\text { studied }\end{array}$ \\
\hline $\begin{array}{l}\text { Journal of } \\
\text { Managing } \\
\text { Service Quality } \\
\text { Volume: } 24 \\
\text { Issue: } 5 \\
\text { Pages: } 455-468 \\
\end{array}$ & $\begin{array}{l}\text { Developing life } \\
\text { insurer-insurance } \\
\text { intermediary } \\
\text { relationships }\end{array}$ & $\begin{array}{l}\text { Tsu-Wei Yu \& } \\
\text { Mei-Su Chen }\end{array}$ & 2014 & $\begin{array}{l}\text { trust, satisfaction, } \\
\text { \& commitment }\end{array}$ & $\begin{array}{l}\text { Taiwan } \\
\text { Supplier- } \\
\text { Distributor } \\
\text { Relationships. }\end{array}$ \\
\hline $\begin{array}{l}\text { Journal of Indian } \\
\text { Business } \\
\text { Research } \\
\text { Volume: } 10 \\
\text { Issue:2 } \\
\text { Pg:170-192 }\end{array}$ & $\begin{array}{l}\text { Relationship } \\
\text { Orientation in } \\
\text { Banking and } \\
\text { Insurance Services - A } \\
\text { Review of The } \\
\text { Evidence }\end{array}$ & $\begin{array}{l}\text { Ankitha Shetty \& } \\
\text { Savitha Basri }\end{array}$ & 2017 & $\begin{array}{l}\text { trust, satisfaction, } \\
\text { \& commitment }\end{array}$ & $\begin{array}{l}\text { India } \\
\text { Customer-Sales } \\
\text { Representative } \\
\text { Relationship }\end{array}$ \\
\hline $\begin{array}{l}\text { The Journal of } \\
\text { Business } \\
\text { Perspective } \\
\text { Volume: } 17 \\
\text { Issue: } 4 \\
\text { Pg:285-292 }\end{array}$ & $\begin{array}{l}\text { Effects of Service } \\
\text { Quality and } \\
\text { Salesperson } \\
\text { Characteristics on } \\
\text { Consumer Trust and } \\
\text { Relationship } \\
\text { Commitment: An } \\
\text { Empirical Study on } \\
\text { Insurance Buyers in } \\
\text { India }\end{array}$ & Tapan K. Panda & 2013 & $\begin{array}{l}\text { trust \& } \\
\text { commitment }\end{array}$ & India \\
\hline $\begin{array}{l}\text { Revista } \\
\text { Portuguesa de } \\
\text { Marketing; Porto } \\
\text { Volume: } 38 \\
\text { Issue: } 35 \\
\text { Pg:55-76 }\end{array}$ & $\begin{array}{l}\text { Communication } \\
\text { Determinants in The } \\
\text { Insurance Industry }\end{array}$ & $\begin{array}{l}\text { Anabela Marcos } \\
\text { \& Arnaldo } \\
\text { Coelho }\end{array}$ & 2015 & $\begin{array}{l}\text { perceived value } \\
\text { reputation } \\
\text { - } \quad \text { service } \\
\text { quality } \\
\text { (interactive } \\
\text { and facility) } \\
\text { - } \quad \text { expertise of } \\
\text { contact } \\
\text { personnel } \\
\text { c customer } \\
\end{array}$ & $\begin{array}{l}\text { Portugal } \\
\text { insurance } \\
\text { holders and the } \\
\text { insurance } \\
\text { companies }\end{array}$ \\
\hline
\end{tabular}


orientation

\begin{tabular}{|c|c|c|c|c|c|}
\hline $\begin{array}{l}\text { Journal of } \\
\text { Managing } \\
\text { Service Quality } \\
\text { Volume: } 23 \\
\text { Issue: } 2 \\
\text { Pages: } 455-468 \\
\end{array}$ & $\begin{array}{l}\text { Investigating Effects } \\
\text { of Relationship } \\
\text { Marketing Types In } \\
\text { Life Insurers in } \\
\text { Taiwan }\end{array}$ & $\begin{array}{l}\text { Tsu-Wei Yu \& } \\
\text { Feng-Cheng } \\
\text { Tung }\end{array}$ & 2013 & $\begin{array}{l}\text { trust, satisfaction, } \\
\text { \& commitment }\end{array}$ & $\begin{array}{l}\text { Taiwan } \\
\text { policyholder } \\
\text { service centers }\end{array}$ \\
\hline $\begin{array}{l}\text { Kuwait Chapter } \\
\text { of Arabian } \\
\text { Journal of } \\
\text { Business and } \\
\text { Management } \\
\text { Review } \\
\text { Volume: } 3 \\
\text { Issue: } 9 \\
\text { Pages: } 406-420\end{array}$ & $\begin{array}{l}\text { The Impact of } \\
\text { Relationship } \\
\text { Marketing and New } \\
\text { Product Features on } \\
\text { Customer's } \\
\text { Perceptions And The } \\
\text { Intention Of Their } \\
\text { Acceptance In Life } \\
\text { And Investment } \\
\text { Insurance }\end{array}$ & $\begin{array}{l}\text { Mona Oruji } \\
\text { Mohammad } \\
\text { Hassanzadeh, } \\
\text { Mohammad Feizi }\end{array}$ & 2014 & $\begin{array}{l}\text { commitment \& } \\
\text { trust }\end{array}$ & $\begin{array}{l}\text { Iran } \\
\text { relationship } \\
\text { management } \\
\text { strategies on } \\
\text { the acceptance } \\
\text { of a new } \\
\text { product by } \\
\text { customers }\end{array}$ \\
\hline $\begin{array}{l}\text { International } \\
\text { Journal of } \\
\text { Management, } \\
\text { Accounting and } \\
\text { Economics } \\
\text { Volume: } 2 \\
\text { Issue: } 10 \\
\text { Pages: } 1244-1260\end{array}$ & $\begin{array}{l}\text { Effect of Relationship } \\
\text { Marketing on Word of } \\
\text { Mouth in Life } \\
\text { Insurance with the } \\
\text { Approach of } \\
\text { Trust and } \\
\text { Commitment: Case } \\
\text { Study of Karafarin } \\
\text { Insurance Agents in } \\
\text { Mashhad }\end{array}$ & $\begin{array}{l}\text { Saeed Yazdani } \\
\text { Parsa\&Tooraj } \\
\text { Sadeghi }\end{array}$ & 2015 & $\begin{array}{l}\text { commitment \& } \\
\text { trust }\end{array}$ & $\begin{array}{l}\text { Iran } \\
\text { Life insurance } \\
\text { clients }\end{array}$ \\
\hline $\begin{array}{l}\text { Mediterranean } \\
\text { Journal of Social } \\
\text { Sciences } \\
\text { Volume: } 2 \\
\text { Issue: } 2 \\
\text { Pages: } 9-17\end{array}$ & $\begin{array}{l}\text { The Impact of } \\
\text { Relationship } \\
\text { Marketing on the } \\
\text { Performance of } \\
\text { Insurance } \\
\text { Organization }\end{array}$ & $\begin{array}{l}\text { Festus M. } \\
\text { Epetimehin } \\
\text { Joseph }\end{array}$ & 2011 & $\begin{array}{l}\text { relationship } \\
\text { quality, } \\
\text { satisfaction, } \\
\text { insurance } \\
\text { commitment \& } \\
\text { trust }\end{array}$ & $\begin{array}{l}\text { Lagos } \\
\text { Metropolis, } \\
\text { Nigeria }\end{array}$ \\
\hline $\begin{array}{l}\text { International } \\
\text { Journal of } \\
\text { Science, } \\
\text { Technology and } \\
\text { Humanities } \\
\text { Service } \\
\text { Volume:1 } \\
\text { Issue: } \\
\text { Pages: } 68-72\end{array}$ & $\begin{array}{l}\text { Service Quality on } \\
\text { Relationship } \\
\text { Marketing and } \\
\text { Customers' Buying } \\
\text { Behavior Reference To } \\
\text { Health Insurance } \\
\text { Industry In } \\
\text { Coimbatore }\end{array}$ & $\begin{array}{l}\text { R. Murugesan } \\
\text { and } \\
\text { P.Thirumoorthi }\end{array}$ & 2014 & $\begin{array}{l}\text { trust, relationship } \\
\text { commitment, } \\
\text { relationship } \\
\text { satisfaction, } \\
\text { bonding and } \\
\text { communication }\end{array}$ & India \\
\hline $\begin{array}{l}\text { Journal } \\
\text { Marketing and } \\
\text { Branding } \\
\text { Research } \\
\text { Volume:3 } \\
\text { Issue: } \\
\text { Pages: } 41-49\end{array}$ & $\begin{array}{l}\text { The Impact of } \\
\text { Relationship } \\
\text { Marketing on } \\
\text { Customer Loyalty } \\
\text { Enhancement (Case } \\
\text { Study: Kerman Iran } \\
\text { Insurance Company) }\end{array}$ & $\begin{array}{l}\text { AbdolazizAbtin\& } \\
\text { Mostafa } \\
\text { Pouramiri }\end{array}$ & 2016 & $\begin{array}{l}\text { Trust } \\
\text { Satisfaction } \\
\text { Management } \\
\text { Communication } \\
\text { Competent }\end{array}$ & Iran \\
\hline
\end{tabular}


Based on the review earlier literature, this research finally suggested three import key characteristics from the various literature of relationship marketing specifically focus in the insurance industry.

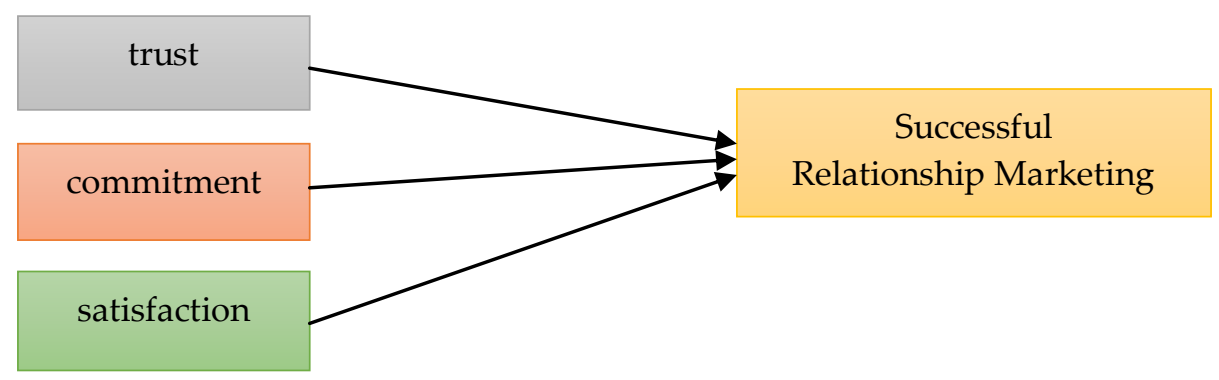

Figure 2: Proposed Conceptual Framework of Successful Relationship Marketing in Insurance Industry.

\section{Conclusions}

The findings from this study have been limited due to the methodological constraints that resulted from the nature of the database searches of published journal articles. The researchers sample consist of journal articles, however the further additional materials such as books and conference papers may also provide an insight of knowledge transfer but were not included in this paper. Nevertheless, it is reasonable to assume that the findings in this paper represent the main research efforts in the relationship marketing towards the insurance industry.

The researcher have sought to provide an overview of relationship marketing in insurance industry which is relatively limited (Shetty \& Basri, 2017). In addition, this review also helps to identify a set of common key characteristics that influence the successful relationship marketing in insurance industry. Based on literature review, further discussion can be used by insurance marketers as one of the tools in marketing the complex intangible product towards their consumer since the consumer are the vital resources of insurance market. These studies can be a basis for the Bank Negara Malaysia, insurance players, intermediaries and other related stakeholder to produce integrated model as a practical guide for the insurance company in their marketing strategies that are in line with the consumer's needs and wants.

This literature review of relationship marketing in insurance industry may open further discussion in area of multidimensional perspective of relationships, the area of relationship marketing should enlarge to studies the potential interactions among the customers, intermediaries and insurance players. Additional research on the seller factors for example seller expertise, seller disclosure, product knowledge, creativity and process knowledge.

\section{Acknowledgments}

The researchers would like to acknowledge colleagues who has helped with the study and offered critical comments about the content. Moreover, the researchers wish to sincerely thank the Universiti Teknologi MARA Cawangan Melaka fortheir permission and sources of funding and anonymous reviewers for their helpful and constructive comments during the development for this paper.

\section{References}

Abtin, A., \& Pouramiri, M. (2016). The impact of relationship marketing on customer loyalty enhancement (Case study: Kerman Iran insurance company). Marketing and Branding Research, 3, 41-49. Retrieved from https://search.proquest.com/docview/1794647406?pq-origsite=gscholar

Anabela, M., \& Arnaldo, C. (2015). Communication determinants in the insurance industry. Revista 
Portuguesa de Marketing; Porto, Vol. 38(Iss. 35), 55-76. Retrieved from https://search-proquestcom.ezaccess.library.uitm.edu.my/abicomplete/docview/1872194555/fulltextPDF/F60869BAAD9 94B83PQ/3?accountid $=42518$

Berry, L. (1983). Relationship Marketing. In Emerging Perspectives on Services Marketing , 25-28.

Echchakoui, S. (2015). Drivers of sales force equity in the service industry. Journal of Retailing and Consumer Services, 27, 140-153. https://doi.org/10.1016/j.jretconser.2015.07.013

Echchakoui, S. (2016). Relationship between sales force reputation and customer behavior: Role of experiential value added by sales force. Journal of Retailing and Consumer Services, 28, 54-66. https://doi.org/10.1016/j.jretconser.2015.07.014

Grönroos, C. (2004). The relationship marketing process: communication, interaction, dialogue, value. Journal of Business \& Industrial Marketing, 19(2), 99-113. https://doi.org/10.1108/08858620410523981

Gummesson, E. (2002). Relationship Marketing in the New Economy. Journal of Relationship Marketing, 1(1), 37-57. https://doi.org/10.1300/J366v01n01_04

Lai, F., Griffin, M., \& Babin, B. J. (2009). How quality, value, image, and satisfaction create loyalty at a Chinese telecom. Journal of Business Research, 62(10), 980-986. https://doi.org/10.1016/J.JBUSRES.2008.10.015

Life Insurance Association Malaysia (LIAM). (2016). Insurance Industry: Key Financial Pillar of Malaysia. MGCC Perspectives The Business Magazine of Malaysian-German Chamber of COmmerce and Industry, 22(8818), 6-8. Retrieved from http://www.malaysia.ahk.de/fileadmin/ahk_malaysia/Perspectives/MGC046Jan.Feb16_iPAD.pdf

Madhavaram, S., Granot, E., \& Badrinarayanan, V. (2004). Relationship marketing strategy: an operant resource perspective. Journal of Business \& Industrial Marketing Journal of Services Marketing Journal of Business Eamp; Industrial Marketing, 29(2), 275-283. Retrieved from https://doi.org/10.1108/JBIM-02-2013-0049

Mark Richard Greene. (2017). insurance I Britannica.com. In Encyclopædia Britannica, Inc. Retrieved from https://www.britannica.com/topic/insurance

Moorman, C., Zaltman, G., \& Deshpandé, R. (1992). Relationships between Providers and Users of Market Research: The Dynamics of Trust within and between Organizations. Retrieved from https://www.hbs.edu/faculty/Pages/item.aspx?num=7269

Morgan, R. M., \& Hunt, S. D. (1994). The commitment-trust theory of relationship marketing. Journal of Marketing, 58(3), 20-38. https://doi.org/10.1177/1356766710391135

Murugesan, R., \& Thirumoorthi, P. (2014). Service quality on relationship marketing and customers' buying behaviuor reference to health insurance industry in Coimbatore. International Journal of Science, Technology and Humanities, 1, 68-72. Retrieved from http://www.svmcugi.com/ijsth/issue1/ijsth13.pdf

Nancy M. Puccinelli, Susan A. Andrzejewski, Ereni Markos, Tracy Noga, \& Scott Motyka. (2013). The value of knowing what customers really want: The impact of salesperson ...: Multimedia University Library Integrated Access (MULiA). Journal of Marketing Management., 29(3-4), 356373. https://doi.org/10.1080/0267257X.2013.766631

O'Malley, L., \& Prothero, A. (2004). Beyond the frills of relationship marketing. Journal of Business Research, 57(11), 1286-1294. https://doi.org/10.1016/S0148-2963(02)00450-2

Palmatier, R. W. (2008). Relationship Marketing. Marketing Science Institute. Retrieved from http://www.mktgsensei.com/AMAE/Services/Relationship Marketing.pdf

Palmatier, R. W., Dant, R. P., Grewal, D., \& Evans, K. R. (2006). Factors Influencing the Effectiveness of Relationship Marketing: A Meta-Analysis. Journal of Marketing. https://doi.org/10.1509/jmkg.70.4.136

Palmatier, R. W., Scheer, L. K., Evans, K. R., \& Arnold, T. J. (2008). Achieving relationship marketing effectiveness in business-to-business exchanges. Journal of the Academy of Marketing Science, 36(2), 174-190. https://doi.org/10.1007/s11747-007-0078-5 
Panda, T. K. (2013). Effects of service quality and salesperson characteristics on consumer trust and relationship commitment: an empirical study on insurance buyers in India. Vision: The Journal of Business Perspective. https://doi.org/10.1177/0972262913505370

Rackham, N., \& DeVincentis, J. (1999). Rethinking the sales force: redefining selling to create and capture customer value. McGraw-Hill, 25-27. Retrieved from http://www.altfeldinc.com/pdfs/salesforce.pdf

Rajeswari, D. K., \& Kartheeswari, S. (2011). Perception of customers towards life insurance services. $A P J R B M, 2(12)$. Retrieved from http://www.skirec.com

Sharma, A., Tzokas, N., Saren, M., \& Kyziridis, P. (1999). Antecedents and consequences of relationship marketing. Industrial Marketing Management. https://doi.org/10.1016/S00198501(98)00034-0

Shetty, A., \& Basri, S. (2017). Relationship orientation in banking and insurance services - a review of the evidence. Journal of Indian Business Research Journal of Indian Business Research Journal of Indian Business Research, 10(2), 170-192. Retrieved from https://doi.org/10.1108/JIBR-10-2017-0176

Sieg, J. H., Fischer, A., Wallin, M. W., \& Von Krogh, G. (2013). Journal of Service Management Proactive diagnosis: how professional service firms sustain client dialogue) \&quot;Proactive diagnosis: how professional service firms sustain client dialogue\&quot; Proactive diagnosis: how professional service firms sustain. Journal of Service Management Journal of Service Management Iss Journal of Business Eamp; Industrial Marketing, 23(8), 253-278. Retrieved from https://doi.org/10.1108/09564231211226132

Šonková, T., \& Grabowska, M. (2015). Customer engagement: transactional vs. relationship marketing. Journal of International Studies. https://doi.org/10.14254/2071-8330.2015/8-1/17

Sweeney, J. C., Soutar, G. N., \& Mccoll-kennedy, J. R. (2011). The marketing practices-performance relationship in professional service firms. Journal of Service Management Journal of Services Marketing, 22(5), 292-316. Retrieved from https://doi.org/10.1108/09564231111136845

Webster Jr., F. E. (1994). Defining the New Marketing Concept. Retrieved May 23, 2018, from http://connection.ebscohost.com/c/articles/9602160669/defining-new-marketing-concept

Weiss, A. M., Anderson, E., \& MacInnis, D. J. (1999). Reputation management as a motivation for sales structure decisions. Journal of Marketing, 63(4), 74. https://doi.org/10.2307/1251975

Whyatt, G., \& Koschek, R. (2003). Implementing relationship marketing: supermarkets' perspectives. Marketing Intelligence \& Planning, 28(3), 582-599. Retrieved from https://doi.org/10.1108/02634501011066519

Winter, S. G. (2003). Understanding dynamic capabilities. Strategic Management Journal, 24(10), 991995. https://doi.org/10.1002/smj.318

Woodruff, R. B. (1997). Customer value: The next source for competitive advantage. Journal of the Academy of Marketing Science, 25(2), 139-153. https://doi.org/10.1007/BF02894350

$\mathrm{Yu}, \mathrm{T}$.-W., \& Tung, F.-C. (2014). Antecedents and consequences of insurer-salesperson relationships. Marketing Intelligence $\mathcal{E}$ Planning, 32(4), 436-454. https://doi.org/10.1108/MIP-01-2013-0013

Zeithaml, V. A. (1988). Consumer perceptions of price, quality, and value: a means-end model and synthesis of evidence. Journal of Marketing, 52(3), 2. https://doi.org/10.2307/1251446 